\title{
Mating patterns and genetic diversity in the wild Daffodil Narcissus longispathus (Amaryllidaceae)
}

\author{
SCH Barrett ${ }^{1}$, WW Cole ${ }^{1}$ and CM Herrera ${ }^{2}$ \\ ${ }^{1}$ Department of Botany, University of Toronto, 25 Willcocks Street, Toronto, Ontario, Canada M5S 3B2; ${ }^{2}$ Estación Biológica de Doñana, \\ CSIC, Apartado 1056, E-41080, Sevilla, Spain
}

\begin{abstract}
Despite the importance of Narcissus to ornamental horticulture, there have been no population genetic studies of wild species, many of which have narrow distributions. Here, we measure selfing rates and levels of genetic diversity at allozyme loci in six populations of Narcissus longispathus, a self-compatible daffodil endemic to a few mountain ranges in southeastern Spain. The populations were distributed among four distinct river valleys encompassing two main watersheds in the Sierra de Cazorla mountains. Selfing rates averaged 0.37 (range 0.23-0.46), resulting in significant inbreeding coefficients for the progeny $(f=0.324)$. In contrast, estimates of inbreeding in parental genotypes were not significantly
\end{abstract}

different from zero $(f=0.001)$, indicating that few selfed offspring survive to maturity because of inbreeding depression. Species-wide estimates of genetic diversity for the six populations were $P_{\mathrm{s}}=0.38, H_{\mathrm{es}}=0.119$ and $A_{\mathrm{s}}=1.27$ with significant genetic differentiation among populations $\theta=0.15$. The observed patterns of genetic differentiation among populations are likely influenced by the mating system, and a combination of local topography, watershed affinities and gene flow.

Heredity (2004) 92, 459-465, advance online publication, 10 March 2004; doi:10.1038/sj.hdy.6800441

Keywords: allozymes; genetic diversity; inbreeding depression; Narcissus; selfing rates

\section{Introduction}

Mating patterns in flowering plants are governed by complex interactions between reproductive traits and the ecology of populations (Lloyd, 1980; Holsinger, 1996; Barrett and Pannell, 1999). An important component of mating is the amount of self-fertilization that a population experiences. This is because selfing has direct genetic consequences, including its effect on the intensity of inbreeding depression (Charlesworth and Charlesworth, 1987) and the partitioning of genetic diversity within and among populations (Hamrick and Godt, 1989). In animal-pollinated species, pollen dispersal and levels of selfing may be influenced by the environmental conditions during flowering. Species that bloom in early spring when unfavourable weather conditions often prevail are susceptible to unpredictable pollinator service. Probably as a response to uncertain pollination environments many early blooming herbs possess floral traits, such as extended floral longevities and selfcompatibility, which reduce the likelihood of reproductive failure (Schemske et al, 1978; Barrett and Helenurm, 1987; Herrera, 1995). However, self-compatible species with long floral lifespans may be vulnerable to unpredictable pollinator service, which can potentially result in increased self-fertilization.

The spatial distribution, size and abundance of populations might also be expected to influence mating patterns in animal-pollinated plants. Spatial isolation and

Correspondence: SCH Barrett, Department of Botany, University of Toronto, 25 Willcocks Street, Toronto, Ontario, Canada M5S 3B2.

E-mail: Barrett@botany.utoronto.ca

Received 18 November 2002; accepted 27 January 2004; published online 10 March 2004 small population size generally act to reduce the frequency of pollinator visitation (Åren, 1996), resulting in the potential for increased selfing and local inbreeding. Under these demographic conditions, the selection of self-compatibility through the breakdown of self-incompatibility may be favoured as a means of reproductive assurance (Lloyd, 1980; Piper et al, 1986). This is likely to occur under low-density conditions if populations consistently receive insufficient pollinator service to maintain fertility (Kunin, 1992). Indeed, the reported association between self-compatibility and plant rarity may reflect, in part, the mating constraints that spatial isolation presents for animal-pollinated plants with restricted distributions (Kunin and Shmida, 1997, but see Karron, 1987).

Narcissus longispathus Pugsley (Amaryllidaceae) is a bee-pollinated, perennial herb endemic to a few mountain ranges in southeastern Spain (Moreno Saiz and Sainz Ollero, 1992). It is related to the widely distributed, highly polymorphic, self-incompatible N. pseudonarcissus; the most commonly cultivated trumpet daffodil of horticulture. In a study of the floral biology of $N$. longispathus in the Sierra de Cazorla mountains, Herrera (1995) demonstrated that N. longispathus is self-compatible producing equivalent amounts of seed following experimental self- and cross-pollinations. This contrasts with other species in the genus most of which are moderately to strongly self-sterile (reviewed in Barrett et al, 1996; Sage et al, 1999). In the Sierra de Cazorla mountains, $N$. longispathus is represented by scattered populations confined to stream margins or poorly drained meadow fragments at 1000-1500 m. Flowering occurs from late February to mid-April, a period characterized by cool, rainy weather that frequently limits the activity of the species' main pollinator (Andrena bicolor, Andrenidae). Despite low pollinator visitation, 
most flowers of $N$. longispathus are pollinated. Using controlled crosses, Herrera (1995) demonstrated weak pollen limitation of fruit set, but no evidence that insufficient pollen delivery limits seed set per fruit. To what extent self-fertilization contributes towards the maintenance of female fertility in $N$. longispathus is not known. To address this issue, we investigated the mating system of this species.

There have been no studies of the population genetics of wild daffodil species to evaluate levels of diversity. As $N$. longispathus is a rare endemic closely related to several cultivated species, we were interested in investigating the amounts of genetic diversity within and among populations. Such information may be of value for future efforts for the conservation of gene pools of close relatives of cultivated daffodils. Populations of N. longispathus in the Sierra de Cazorla mountains are distributed among several distinct watersheds and river valleys. Therefore, we were also interested in examining how geographical isolation and watershed membership might influence their genetic relationships.

Here, we address several questions concerning the mating system and population genetic structure of N. longispathus: (1) What rates of self-fertilization occur in populations and are these influenced by population size? (2) Is there evidence of selection against selfed offspring during growth and reproduction due to inbreeding depression? (3) What are the levels of genetic diversity in populations and does their spatial distribution influence genetic relationships? These questions were addressed by sampling seed families from six populations in the Sierra de Cazorla mountains and investigating polymorphism at allozyme loci.

\section{Materials and methods}

\section{Sampling and electrophoresis}

We randomly sampled open-pollinated capsules at maturity from six populations of $N$. longispathus during May-June 1990. The location of populations is mapped in Figure 1 and details of population size and sample sizes for families used in the genetic analyses are provided in Tables 1 and 3. Size of populations was estimated as the number of spatially distinct clumps of ramets. The six populations were distributed among four distinct river valleys encompassing two main watersheds. The Cuevas Bermejas (CB) population is isolated from the remaining populations and is located on a separate watershed (Guadalquivir River). The remaining five populations are distributed among three river valleys within a single watershed (Guadalentín River). Most populations were small but populations $\mathrm{Gu}-\mathrm{C}$ and $\mathrm{Gu}-\mathrm{D}$ were two distinct nuclei, about $200 \mathrm{~m}$ apart, located on opposite banks of the Gualay River, and belonged to a large and more or less continuous population of $\sim 5000$ plants. Data on fluorescent dye movement revealed no dispersal between riverbanks or in excess of $100 \mathrm{~m}$ (CM Herrera, unpublished data), so in this study we considered these two nuclei as separate populations.

We assayed a total of 932 seeds for allozyme variation using electrophoretic techniques. Seeds were ground in $0.02 \mathrm{M} \mathrm{Na} 2 \mathrm{HPO} 4$ buffer ( $\mathrm{pH}$ 7.4) containing DL-dithiothreitol $(1 \mathrm{mg} / \mathrm{ml})$. Extracts were adsorbed onto chromato-

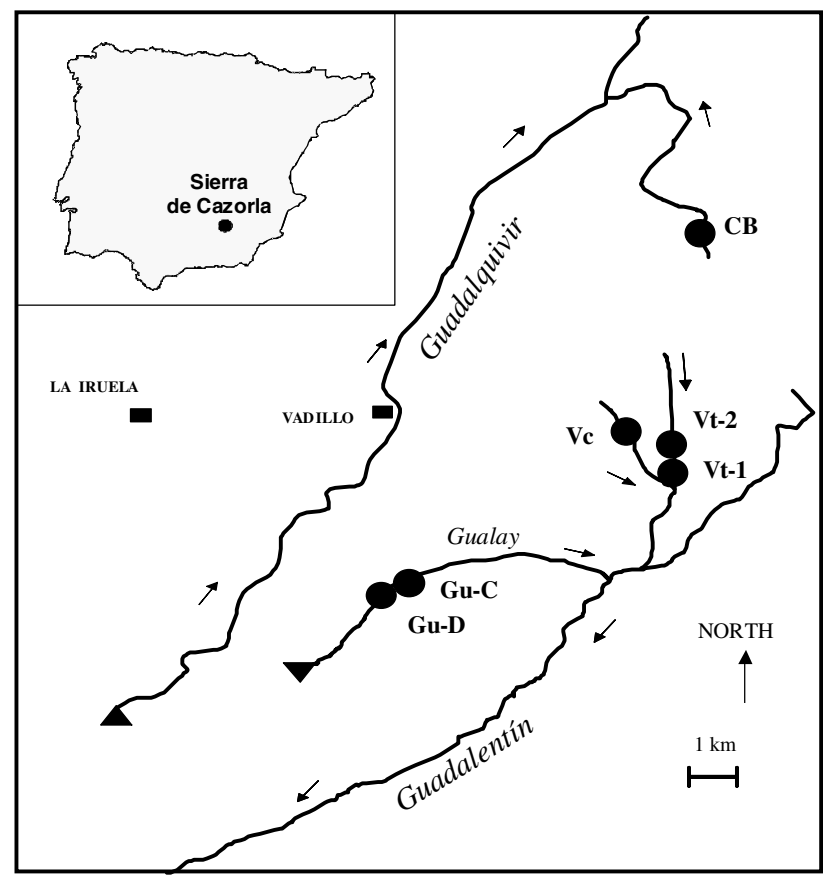

Figure 1 Geographical distribution of six populations of $N$. longispathus sampled from the Sierra de Cazorla mountains, SE Spain. Arrows indicate the direction of flow of water along river valleys.

Table 1 Populations of N. longispathus in the Sierra de Cazorla mountains, SE Spain, which were investigated in this study

\begin{tabular}{llcc}
\hline Code & Population & Population size, $\mathrm{n}$ & Plants sampled \\
\hline CB & Cuevas Bermejas & 40 & 14 \\
Gu-C & Tornillos de Gualay-C & 300 & 12 \\
Gu-D & Tornillos de Gualay-D & 300 & 15 \\
Vc & Valdecuevas & 600 & 15 \\
Vt-1 & Valdetrillos-1 & 250 & 15 \\
Vt-2 & Valdetrillos-2 & 150 & 15 \\
\hline
\end{tabular}

graphy-paper wicks (Whatman $3 \mathrm{~mm}$ ), and placed directly onto 11-12\% starch gels. Enzymes were resolved on two buffer systems: aspartate amino transferase, alcohol dehydrogenase, adeline kinase (AK), fructosebisphosphate aldolase, diaphorase, glutamate dehydrogenase, cytosol aminopeptidase, menadione reductase and triose phosphate isomerase, on lithium borate ( $\mathrm{pH} \mathrm{8.3);}$ and aconitase, acid phosphotase $(\mathrm{ACP})$, creatine kinase, fumarate hydratase, glycerol-3-phosphare dehydrogenase, isocitric dehydrogenase, malate dehydrogenase, peroxidase (PER), phosphoglucose dehydrogenase (6PGD), phosphoglucose isomerase, shikimic dehydrogenase on histidine citrate ( $\mathrm{pH}$ 6.5). Gels were stained for enzyme activity following recipes in Wendel and Weeden (1991). Genotypes at 42 putative allozyme loci were inferred based on segregation patterns characteristic of either dimeric or monomeric codominant enzymes. We used all loci with a minimum of 20 individuals scored per population to estimate proportion of polymorphic loci $(P)$ including three additional loci ( $A C P-1, A K-1, A K-2)$ that were variable but not consistently scoreable. Of the 14 polymorphic loci, $P E R-3$ had a null allele and $6 P G D$ 
had two overlapping loci and were therefore dropped from further analysis.

\section{Estimates of the mating system and inbreeding}

For each population, we estimated single- and multilocus selfing rates ( $S_{S}$ and $S_{M}$, respectively) and the parental inbreeding coefficient $(f)$ using the computer program MLTR (version 0.9. Ritland, 1990a). Selfing rates in each population were based on polymorphism at seven allozyme loci. Standard errors of the selfing rate estimates were derived from the standard deviation of 1000 bootstrap values, using the seed family as the unit of resampling. Expectation maximization was used to find maximum-likelihood estimates of all mating system parameters because some families had missing data. We examined the intensity of biparental inbreeding within each population by determining the difference between the mean of single- and multilocus estimates of selfing $\left[\left(S_{S}-S_{M}\right) /\left(1-S_{M}\right)\right]$, see Waller and Knight (1989). Inbreeding depression ( $\delta=1$-fitness of selfed progeny/ fitness of outcrossed progeny) for survival from seed to reproductive maturity was calculated for each population by substituting the estimates of multilocus selfing rate $\left(S_{M}\right)$ and parental inbreeding coefficient $(f)$ into Ritland's (1990b) equilibrium estimator of inbreeding:

$$
\hat{\delta}=1-2\left(\frac{((1-\hat{S}) \hat{f})}{(\hat{S}(1-\hat{f}))}\right)
$$

This estimator allows calculation of inbreeding depression when information is available from one generation, but requires an assumption of inbreeding equilibrium. Standard errors for all mating system parameters were estimated from the standard deviation of 1000 bootstrap estimates. For tests of statistical significance, we examined the distribution of 1000 bootstrap values following Eckert and Barrett (1994). Using this method, a one-tailed test of a given parameter was considered to be significantly higher than the test value if $100\left(1-\alpha_{\mathrm{PC}}\right) \%$ of the bootstrap values were greater than the test value. Critical $P$-values $\left[\alpha_{\mathrm{PC}}=1-(1-0.05)^{1 / \mathrm{C}}\right]$ were corrected for multiple contrasts ( $\alpha_{\mathrm{PC}}=0.00851, C=6$ populations) Sidáks (1967). We calculated biparental inbreeding and inbreeding depression for each bootstrap estimate using outcrossing rates and parental $f$ from Ritland's (1990a) mating system program (MLTR).

\section{Measures of genetic variation and relationships among populations}

We estimated genetic parameters for each population of $N$. longispathus using the programme BIOSYS (Swofford and Selander, 1981). These included: $P$, the percentage of loci that were polymorphic (frequency of the most common allele $<0.95)$, $H$ e, the expected heterozygosity or gene diversity and $A$, the mean number of alleles per locus. We also calculated the equivalent species-level parameters $(P \mathrm{~s}$, percentage of loci polymorphic, Hes, gene diversity and $A s$, the number of alleles over all loci).

We examined hierarchical population structure using Weir and Cockerham's (1984) unbiased estimators of Wright's F-statistics $\left(F_{\text {is }}, F_{\text {st }}\right.$ and $F_{\text {it }}$ denoted hereafter as $f$, $\theta, F$, respectively. We used Goudet's (1997) FSTAT program (Ver. 3.0) to calculate these parameters and their $95 \%$ confidence intervals (bootstrapping over loci). We examined the relation between geographic and genetic distance using GENEPOP version 3.3 (Raymond and Rousset, 1995). This approach examines the relation between $\ln$ (distance) and $\theta /(1-\theta)$ as a measure of genetic distance. Statistical support for isolation by distance was calculated with a Mantel test using 5000 random permutations.

We formulated an a priori hypothesis of genetic similarity among populations of $N$. longispathus from their spatial distribution among the river valleys and watersheds (Figure 1). Populations in the same valley and watershed should be most similar genetically (eg $\mathrm{Gu}-\mathrm{C}, \mathrm{Gu}-\mathrm{D}$, and Vt-1, Vt-2) and those from adjacent valleys should be more similar to one another than populations in valleys farther apart. Populations in different watersheds should be most divergent. We used restricted maximum likelihood to estimate a maximumlikelihood tree based on the gene frequencies of populations (CONTML: Phylip Ver. 3.6; Felsenstein, 2000). From the hypothesized watershed associations, we used the defined tree option to specify the branching topology with a basal trifurcation, a requirement of Phylip $\{[\mathrm{Vc}$, (Vt-1, Vt-2)], (Gu-C, Gu-D), CB\}. We estimated branch lengths from the maximum-likelihood fit to the gene frequency data and used log-likelihood tests to compare the best maximum-likelihood tree estimated from the data with: (1) a tree constrained to have the branching topology of the hypothesized watershed relations and (2) a tree based on geographic distance.

\section{Results}

\section{Mating patterns and inbreeding}

We detected moderate frequencies of self-fertilization in each of the six populations of $N$. longispathus (mean $S_{M}=0.37$, range 0.23-0.46, Figure 2). There were significant differences between single- and multilocus estimates of selfing in five of the six populations indicating the occurrence of inbreeding among outcrossed progeny (Table 2). There was no evidence for a relation between population size and the mean frequency of self-fertilization (one-way ANOVA, $\mathrm{F}=0.67$, $P=0.70$ ), or biparental inbreeding (one-way ANOVA, $\mathrm{F}=1.30, \quad P=0.32$ ). The mean inbreeding depression among the six populations of $N$. longispathus was $\delta=0.77$. Inbreeding depression was significantly greater than zero in four of the six populations sampled (Table 2).

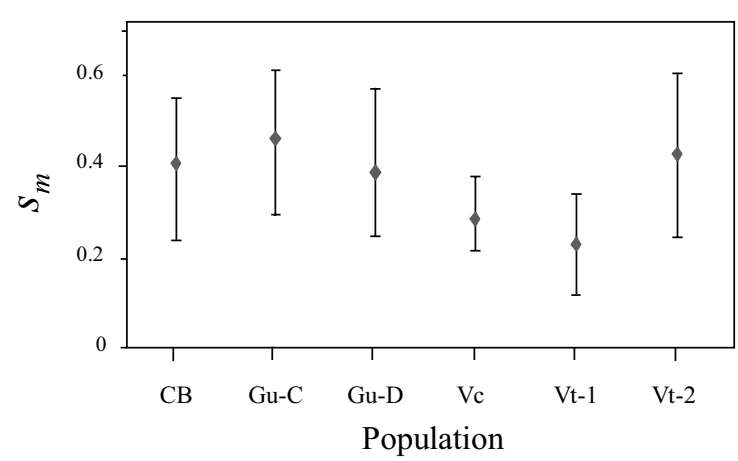

Figure 2 Mean multilocus selfing rates with 95\% range of 1000 bootstrap estimates from six populations of $N$. longispathus sampled from the Sierra de Cazorla mountains, SE Spain. 
Table 2 Estimates of multilocus and single locus selfing rates (with SE), biparental inbreeding, parental inbreeding coefficient and inbreeding depression $(\delta)$ in populations of $N$. longispathus from SE Spain

\begin{tabular}{lccccccc}
\hline Population code & Multilocus selfing, $S_{M}$ & Single-locus selfing, $S_{S}$ & Biparental inbreeding & $P^{a}$ & $F$ of parents & $\delta$ & $P$, $\delta>0$ \\
\hline CB & $0.405(0.081)$ & $0.472(0.085)$ & 0.114 & $0.007^{* *}$ & $0.031(0.023)$ & $0.906(0.089)$ & $P<0.001$ \\
Gu-C & $0.461(0.084)$ & $0.491(0.089)$ & 0.056 & 0.162 NS & $-0.351(0.269)$ & $1.608(0.492)$ & $P<0.001$ \\
Gu-D & $0.387(0.082)$ & $0.461(0.063)$ & 0.121 & $0.035^{*}$ & $0.015(0.007)$ & $0.952(0.043)$ & $P<0.001$ \\
Vc & $0.281(0.040)$ & $0.384(0.048)$ & 0.143 & $<0.001^{* * *}$ & $0.132(0.084)$ & $0.222(0.602)$ & $P=0.208$ \\
Vt-1 & $0.226(0.057)$ & $0.316(0.066)$ & 0.116 & $0.005^{* *}$ & $0.112(0.072)$ & $0.136(2.0)$ & $P=0.277$ \\
Vt-2 & $0.427(0.090)$ & $0.529(0.087)$ & 0.178 & $<0.001^{* * *}$ & $0.005(0.001)$ & $0.987(0.004)$ & $P<0.001$ \\
\hline
\end{tabular}

NS $=$ nonsignificant

${ }^{a} P$ calculated as the fraction of 1000 bootstrap estimates.

Table 3 Allozyme diversity of N. longispathus populations from Sierra de Cazorla, SE Spain

\begin{tabular}{lcccc}
\hline Population & $\begin{array}{c}\text { Mean sample size per } \\
\text { polymorphic locus }\end{array}$ & $\begin{array}{c}\text { Proportion loci } \\
\text { polymorphic } P, N \text { loci }\end{array}$ & $\begin{array}{c}\text { Genetic diversity } \\
H_{e}(S E), N \text { loci }\end{array}$ & $\begin{array}{c}\text { Mean number of alleles } \\
A_{p}(S E), N \text { loci }\end{array}$ \\
\hline $\mathrm{CB}$ & 127.2 & $0.33,40$ & $0.117(0.021), 36$ & $1.36(0.07), 36$ \\
$\mathrm{Gu}-\mathrm{C}$ & 87.2 & $0.29,41$ & $0.086(0.020), 37$ & $1.28(0.14), 37$ \\
$\mathrm{Gu}-\mathrm{D}$ & 100.3 & $0.28,43$ & $0.084(0.018), 39$ & $1.40(0.13), 39$ \\
$\mathrm{Vc}$ & 112.1 & $0.33,42$ & $0.072(0.018), 38$ & $1.27(0.14), 38$ \\
$\mathrm{Vt}-1$ & 80.4 & $0.35,37$ & $0.086(0.021), 34$ & $1.46(0.13), 34$ \\
$\mathrm{Vt}-2$ & 59.9 & $0.29,34$ & $0.091(0.020), 33$ & $1.32(0.15), 33$ \\
Species level & 577.8 & $0.38,45$ & $0.119(0.014), 45$ & $1.27(0.07), 45$ \\
\hline
\end{tabular}

The two populations ( $\mathrm{Vc}, \mathrm{Vt}-1)$ in which estimates of inbreeding depression were not significantly different from 0 had the lowest selfing rates and the largest estimates of parental $f$.

Estimates of inbreeding indicated significant inbreeding in progeny of $N$. longispathus $(f=0.365,95 \%$ $\mathrm{CI}=0.288,0.446)$ and a overall significant deficit of heterozygotes $(F=0.461,95 \% \mathrm{CI}=0.383,0.539)$. Parallel analysis on the inferred maternal genotypes of parents indicated that they were not inbred $(f=0.001,95 \%$ $\mathrm{CI}=-0.120,0.102)$, a result consistent with strong selection against inbred progeny.

\section{Measures of genetic variation}

The values for proportion of loci polymorphic, number of alleles per locus and expected heterozygosity in populations of $N$. longispathus are presented in Table 3. Values for total genetic diversity, diversity within populations and genetic differentiation among populations were $H \mathrm{t}=0.315, H \mathrm{~s}=0.264, \mathrm{Gst}=0.165$, respectively. The significant genetic differentiation among populations of $N$. longispathus was also revealed from the hierarchical analysis of gene diversity, $\theta=0.150$, 95\% $\mathrm{CI}=0.114,0.195$.

\section{Genetic relations among populations}

There was a significant relation between the genetic distance and geographic distance of $N$. longispathus populations (Mantel test, $P=0.0134$ ). However, although populations $\mathrm{Gu}-\mathrm{C}$ and $\mathrm{Gu}-\mathrm{D}$ clustered together, populations Vt-1 and Vt-2 were more divergent from each other than expected based on their geographical proximity. Population $\mathrm{CB}$, the only population in a different watershed was relatively distant from all population except Vt-2. A maximum-likelihood tree based on the gene frequency data illustrates these relationships

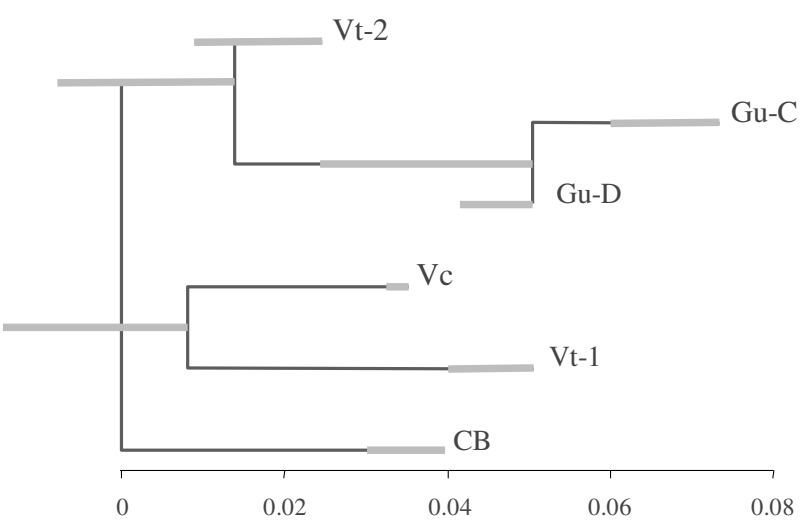

Figure 3 Genetic relationships among six populations of $N$. longispathus sampled from the Sierra de Cazorla mountains, SE Spain, based on the maximum-likelihood fit to the gene frequency data. $\log$ likelihood $=78.78$ calculated using the PHYLIP CONTML option (see Materials and methods). The shaded bars indicate the 95\% confidence interval for each branch and units are amounts of expected variance accumulated.

(Figure 3). This tree was not significantly different from trees based on the watershed affinity hypothesis $(\Delta \log$ likelihood $=-0.9, \mathrm{SD}=1.51)$, and a tree generated from geographic distances $(\Delta \log$ likelihood $=-56.0$, $\mathrm{SD}=40.89$ )

\section{Discussion}

Our estimates of mating patterns in N. longispathus indicated moderate levels of selfing in each of the six populations, but we found no evidence that population size influenced rates of selfing or biparental inbreeding. An inverse relationship between population size and selfing rates has been found for some self-compatible 
plants with mixed mating systems (Raijmann et al, 1994; Routley et al, 1999), but not for others (Burdon et al, 1988; van Treuren et al, 1993). In Salvia pratensis (van Treuren et al, 1993) population density, rather than population size, was inversely related to selfing rate. Variation in plant density among our $N$. longispathus populations might account for a component of the observed variation in selfing rate, but data required to test this are not available.

Despite considerable variation in population size and the local ecological conditions of populations, the range of selfing estimates was relatively narrow (Figure 2). This result raises the possibility that $N$. longispathus possesses postpollination physiological mechanisms that regulate mating patterns. Although N. longispathus is self-compatible (Herrera, 1995), it is possible that outcross pollen tubes grow faster than self-pollen tubes, resulting in higher frequencies of outcrossing than selfing (Bateman, 1956). Such 'cryptic self-incompatibility' may limit variation in selfing rates and buffer populations against the uncertain pollination environments that are common in early spring. Studies of pollen tube growth following self- and cross-pollination could corroborate this hypothesis.

Our estimates of inbreeding in the progeny of $N$. longispathus indicated a significant deficit of heterozygotes. Yet, analysis of the maternal genotypes of parents indicated that they were largely the products of outbreeding. This suggests that selfed offspring of $N$. longispathus do not survive to reproductive maturity. The most probable mechanism causing differential survival of selfed and outcrossed progeny is inbreeding depression. Indeed, in four of the six populations that we sampled, estimates of inbreeding depression were close to one, implying strong selection against selfed progeny. Estimates of inbreeding depression in several other plant species with mixed mating systems indicate very low survival of selfed offspring in comparison with outcrossed offspring (eg Eckert and Barrett, 1994; Routley et al, 1999; Dorken et al, 2002). The moderate levels of selfing we detected in $N$. longispathus may represent a cost that occurs, in part, because of the combination of long-lived flowers and small-scale clonal propagation via spontaneous bulb splitting. Although the vast majority of $N$. longispathus ramets bear single flowers, up to five to six flowers may remain open simultaneously for up to 2 weeks in small $(30-50 \mathrm{~cm}$ across) clumps of ramets that presumably originated from successive bulb splitting and thus correspond to a single genotype. This may result in a significant component of selfing arising through geitonogamous self-pollination.

Since selfed offspring appear to survive rarely in $N$. longispathus, it is interesting to consider under what conditions self-compatibility might serve an adaptive function, by providing reproductive assurance. Most other Narcissus species are protected from the genetic costs associated with selfing through the action of selfsterility, although like $N$. longispathus the early-spring flowering $N$. dubius is also fully self-compatible (Baker et al, 2000). It is possible that low survival of selfed offsping is typical for well-established populations of $N$. longispathus (such as those we examined), but under demographic conditions associated with the founding of new colonies selfed offspring could have greater opportunities for survival and reproduction. Self-compatibility in N. longispathus may have had its historical origins during the colonization of the Sierra de Cazorla mountains when small population sizes could have restricted mating opportunities.

Although analyses of genetic diversity in species with widespread $v s$ restricted distributions have often revealed reduced variation in rare species (Karron, 1987; 1997; Hamrick and Godt, 1989; Gitzendanner and Soltis, 2000), species classified as rare are by no means a homogeneous group (Rabinowitz, 1981). Thus, it is not altogether unexpected that some species with restricted geographical distributions maintain levels of genetic diversity comparable to their widespread congeners. Indeed, in their literature survey of allozyme variation in congeneric species, Gitzendanner and Soltis (2000) found that $24-29 \%$ of the rare species they examined were as variable or more variable than their widespread congeners. Unfortunately, since population surveys of allozyme variation have yet to be conducted on other wild species of Narcissus, it is not possible to compare our values to those from more widespread species in section Pseudonarcissus (eg $N$. asturiensis, $N$. nobilis, $N$. pseudonarcissus). Nevertheless, our results indicate that there is no evidence that the restricted distribution of $N$. longispathus is associated with the severe erosion of genetic diversity. Habitat stability, low population turnover, high outcrossing and selection against selfed offspring are all likely to favour the maintenance of genetic variation in population of $N$. longispathus.

Although there are numerous investigations of watershed influences on the genetic relationships of animal populations, particularly fish species (reviewed in Avise, 1994), few studies of plants have been conducted (eg Harris et al, 1992; Rogers et al, 1999; Butcher et al, 2002). Ritland (1989) found compelling evidence supporting a watershed-driven hierarchy of genetic relationships in 22 populations of the perennial herb Mimulus caespitosus. Our analyses of the genetic relationships among populations of $N$. longispathus provided some support for the hypothesis that populations occurring in the same river valley or watershed were more likely to be similar than those in different valleys or watersheds (Figure 3). Given the complex topography of the Sierra de Cazorla, gene flow is more likely to occur along river valleys than across the rugged mountainous terrain between valleys where ecological conditions are generally not suitable for populations of $N$. longispathus to occur. Nevertheless, our sample of $N$. longispathus populations was too limited to detect a clear pattern of genetic relationship and larger samples would be required to investigate the spatial genetic structure of this species.

Mechanisms of gene flow in N. longispathus are poorly known. Preliminary estimates of pollen dispersal based on deposition curves of fluorescent dye particles indicate that pollen flow is quite local. Exchange between nearby flower patches only dozens of meters away, and dispersal distances $>50 \mathrm{~m}$ along linear populations on river banks, are exceptional (CM Herrera, unpublished observations). Downstream seed dispersal by water and, much less frequently, seeds passing unharmed through the digestive tract of deer browsing on ripe fruits, seem the most likely mechanisms of gene dispersal in this species. Future studies of $N$. longispathus might usefully investigate mechanisms of gene flow and genetic relationships among populations in the Sierra de Cazorla 
mountains and those from other mountain ranges in SE Spain where populations have also been reported (Moreno Saiz and Sainz Ollero, 1992).

\section{Acknowledgements}

We thank M Carrión for assistance with seed collections, and the Consejería de Medio Ambiente, Junta de Andalucía for permission to work in the Sierra de Cazorla. This work was funded by grants from the Natural Sciences and Engineering Research Council of Canada to SCHB and from Ministerio de Ciencia y Tecnología of Spain (Grants PB87-0452 and BOS20001122-C03-01) to CMH.

\section{References}

Ågren J (1996). Population size, pollinator limitation and seed set in the self-incompatible herb Lythrum salicaria. Ecology 77: 1779-1790.

Avise JC (1994). Molecular Markers, Natural History and Evolution. Chapman \& Hall: New York.

Baker AM, Thompson JD, Barrett SCH (2000). Evolution and maintenance of stigma-height dimorphism in Narcissus II. Fitness comparisons between style morphs. Heredity 84: 514-524.

Barrett SCH, Helenurm K (1987). The reproductive biology of boreal forest herbs 1 . Breeding systems and pollination. Can J Bot 65: 2036-2046.

Barrett SCH, Pannell JR (1999). Metapopulation dynamics and mating-system evolution in plants. In: Hollingsworth $\mathrm{P}$ Bateman R, Gornal R (eds) Molecular Systematics and Plant Evolution. Taylor \& Francis: London, pp 74-100.

Barrett SCH, Lloyd DG, Arroyo J (1996). Stylar polymorphisms and the evolution of heterostyly in Narcissus. In: Lloyd DG, Barrett SCH (eds) Floral Biology: Studies on Floral Evolution in Animal-Pollinated Plants. Chapman \& Hall: New York, pp 339-376.

Bateman AJ (1956). Cryptic self-incompatibility in the wallflower: Cheiranthus cheiri L. Heredity 10: 257-261.

Burdon JJ, Jarosz AM, Brown AHD (1988). Temporal patterns of reproduction and outcrossing in weedy populations of Echium plantagineum. Biol J Linn Soc 34: 81-92.

Butcher PA, Otero A, McDonald MW, Moran GF (2002). Nuclear RFLP variation in Eucalyptus camaldulensis Dehnh from northern Australia. Heredity 88: 402-412.

Charlesworth D, Charlesworth B (1987). Inbreeding depression and its evolutionary consequences. Ann Rev Ecol Syst 18: 237-268.

Dorken ME, Friedman J, Barrett SCH (2002). The evolution and maintenance of monoecy and dioecy in Sagittaria latifolia (Alismataceae). Evolution 56: 31-41.

Eckert CG, Barrett SCH (1994). Inbreeding depression in partially self-fertilizing Decodon verticillatus (Lythraceae): population-genetic and experimental analysis. Evolution 48: 952-964.

Felsenstein J (2000). PHYLIP: Phylogenetic Inference Package version 3.6. (alpha 2), distributed by author,. University of Washington: Seattle, http://evolution.genetics.washington. edu/phylip.html.

Gitzendanner MA, Soltis PS (2000). Patterns of genetic variation in rare and widespread plant congeners. Am J Bot 87: 777-787.

Goudet J (1997). Fstat version 3.0: a computer program to calculate F-statistics. (Ver 1.2) published in. J Heredity 86: 485-486.

Harris SA, Maberly SC, Abbott RJ (1992). Genetic variation within and between populations of Myriophyllum alterniflorum DC. Aquat Bot 44: 1-21.
Hamrick JL, Godt MJ (1989). Allozyme diversity in plant species. In: Brown AHD, Clegg MT, Kahler AL, Weir BS (eds) Plant Population Genetics, Breeding and Genetic Resources. Sinauer Associates: Sunderland, USA, pp 43-63.

Herrera CM (1995). Floral biology, microclimate and pollination by ectothermic bees in an early-blooming herb. Ecology 76: 218-228.

Holsinger KE (1996). Pollination biology and the evolution of mating systems in flowering plants. In: Hecht MK, Steere WC, Wallace B (eds) Evolutionary Biology. Plenum Press: New York, pp 107-149.

Karron JD (1987). A comparison of levels of genetic polymorphism and self-compatibility in geographically restricted and widespread plant congeners. Evol Ecol 1: 47-58.

Karron JD (1997). Genetic consequences of different patterns of distribution and abundance. In: Kunin WE, Gaston KJ (eds) The Biology of Rarity. Chapman \& Hall: London, UK, pp 174-189.

Kunin WE (1992). Density and reproductive success in wild populations of Diplotaxis erucoides (Brassicaceae). Oecologia 91: 129-133.

Kunin WE, Shmida A (1997). Plant reproductive traits as a function of local, regional, and global abundance. Conserv Biol 11: 183-192.

Lloyd DG (1980). Demographic factors and mating patterns in angiosperms. In: Solbrig OT (ed) Demography and Evolution in Plant Populations. Blackwell: Oxford, pp 67-88.

Moreno Saiz JC, Sainz Ollero H (1992). Atlas corológico de las monocotiledóneas endémicas de la Península Ibérica y Baleares. ICONA, Ministerio de Agricultura: Madrid.

Piper JG, Charlesworth B, Charlesworth D (1986). Breeding system evolution in Primula vulgaris and the role of reproductive assurance. Heredity 56: 207-217.

Rabinowitz D (1981). Severn forms of rarity. In: Synge H (ed) The Biological Aspects of Rare Plant Conservation. John Wiley \& Sons: Chichester, pp 205-217.

Raijmann LEL, van Leeuwen NC, Kersten R, Oostermeijer JGB, den Nijs HCM, Menken SBJ (1994). Genetic variation and outcrossing rate in relation to population size in Gentiana pneumonanthe L. Conserv Biol 8: 1014-1026.

Raymond M, Rousset F (1995). GENEPOP (version-1.2) Population-Genetics Software for exact tests and ecumenicism. J Heredity 86: 248-249.

Ritland K (1989). Genetic differentiation, diversity, and inbreeding in the mountain monkeyflower (Mimulus caespitosus) of the Washington Cascades. Can J Bot 67: 2017-2024.

Ritland K (1990a). A series of FORTRAN computer programs for estimating plant mating systems. J Heredity 81: 235-237.

Ritland K (1990b). Inferences about inbreeding depression based on changes of the inbreeding coefficient. Evolution 44: 1230-1241.

Rogers DL, Millar CI, Westfall RD (1999). Fine-scale genetic structure of White Bark Pine (Pinus albicaulis): associations with watershed and growth form. Evolution 53: 74-90.

Routley MB, Mavraganis K, Eckert CG (1999). Effect of population size on the mating system in a self-compatible, autogamous plant, Aquilegia canadensis. Heredity 82: $518-528$.

Sage TL, Strumas F, Cole WW, Barrett SCH (1999). Differential ovule development following self- and cross-fertilization in Narcissus triandrus (Amaryllidaceae). Am J Bot 86: 855-870.

Schemske DW, Willson MF, Melampy MN, Miller LJ, Verner L, Schemske KM et al (1978). Flowering ecology of some spring woodland herbs. Ecology 59: 351-366.

Sidák Z (1967). Rectangular confidence regions for the means of multivariate normal distributions. I Am Stat Assoc 62: 626-633.

Swofford DL, Selander RB (1981). Biosys-1: a Fortran program for the comprehensive analysis of electrophoretic data in population genetics and systematics. J Heredity 72: 281-283. 
van Treuren R, Bijlsma R, Ouborg NJ, van Delden W (1993). The effects of population size and plant density on outcrossing rates in locally endangered Salvia pratensis. Evolution 47: 1094-1104.

Waller DM, Knight SE (1989). Genetic consequences of outcrossing in the cleistogamous annual, Impatiens capensis. II. Outcrossing rates and genotypic correlations. Evolution 43: 860-869.
Weir BS, Cockerham CC (1984). Estimating F-statistics for the analysis of population structure. Evolution 38 1358-1370.

Wendel JF, Weeden NF (1991). Visualization and interpretation of plant isozymes. In: Soltis DE, Soltis PS (eds) Isozymes in Plant Biology. Dioscorides Press: Portland, USA, pp 5-45. 